\title{
Bibliometric Analysis of Rural Environmental Governance Research (1957-2020)
}

\author{
Qian Shen ${ }^{1,2}$ \\ ${ }^{1}$ School of Economics, Inner Mongolia University of Finance and Economics, 010070 Hohhot, China \\ ${ }^{2}$ Inner Mongolia Agricultural and Pastoral Area Governance Capacity Modernization Research Base, 010070 Hohhot, China
}

\begin{abstract}
Rural environmental governance is a problem that all countries in the world will face in the process of development. The research on the related literature of Rural environmental governance is helpful to provide reference for practical work. This study uses the Aminer big data analysis platform to analyse relevant research literature on the theme of "Rural environmental governance" from 1957 to 2020. The three research perspectives are: research trends, distribution of academic achievements, and scientific research cooperation networks. The analysis results provide an overall description and judgment of the international Rural environmental governance research.
\end{abstract}

\section{Research methods and research data}

\subsection{Research methods}

Most of the existing literature uses CiteSpace, VOSviewer, gephi and other software for bibliometric analysis[1-6]. There is few literature using a Aminer big data platform for research. This is also the main part that distinguishes this article from other bibliometric studies. This article adopts bibliometric research methods[7] to analyze domestic and foreign research literature on the subject of "Rural environmental governance" in three dimensions.

\subsection{Research data}

The research data in this article comes from the Aminer big data analysis platform, the website is https://www.aminer.cn/. The specific steps are to enter the "Technical Insights" on the website, then click on the "Technical Analysis Self-Service Platform" and enter the keywords "rural management". Thus, we obtained research data. The technical analysis platform is based on Aminer's hundreds of millions of papers and scholar data, and uses massive data to achieve precise search and analysis.

\section{Research trend analysis}

\subsection{Research trends by country}

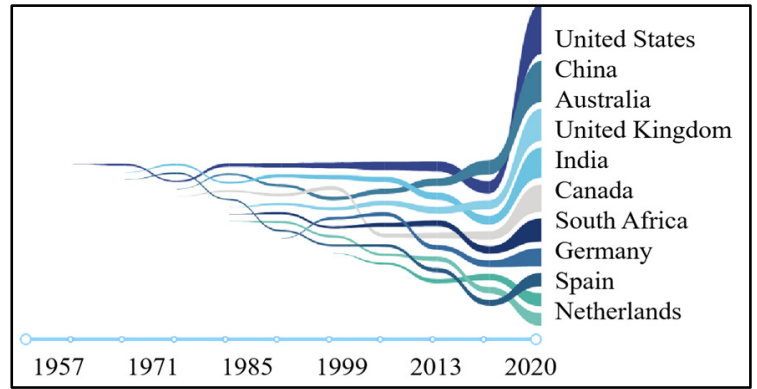

Fig. 1. Top 10 research country

Figure 1 shows that the main research countries related to Rural environmental governance are the United States, China, Australia, the United Kingdom, India, Canada, South Africa, Germany, Spain, and the Netherlands. Among them, related research in the United States was the earliest.

\subsection{Research trends by research hotspots}

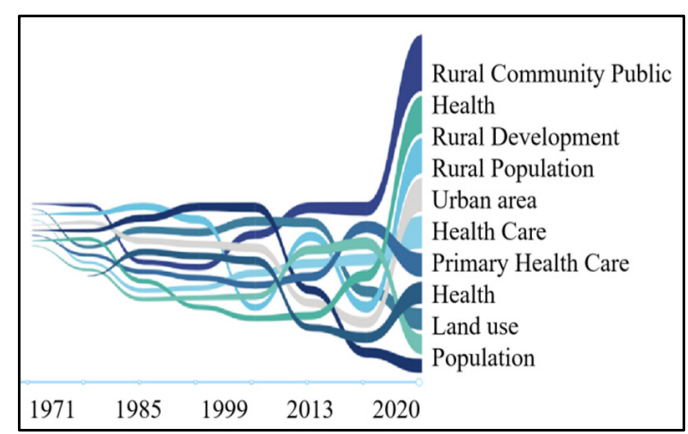

Fig. 2. Top 10 research hotpots

As shown in Figure 2, some research hotspots in this field are: Rural Community, Health, Rural Development, Urban Area, Rural Population, Population, Health Care. 


\subsection{Research trends by research institutes}

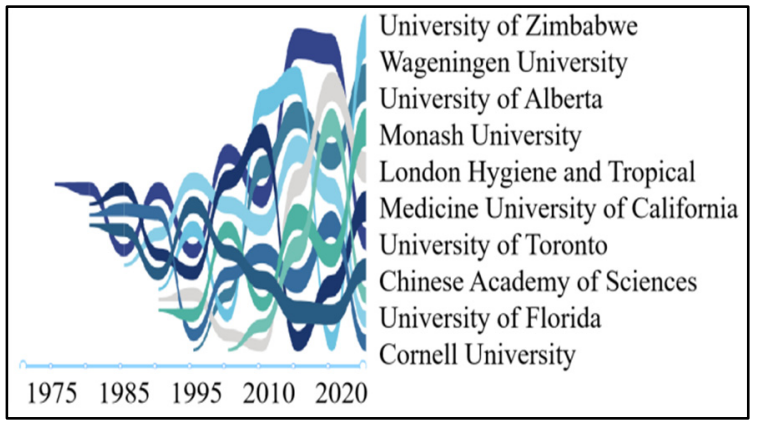

Fig. 3. Top 10 Research institutes

As can be seen in Figure 3, the representative institutions in this field are as follows: University of California, Wageningen University, University of Zimbabwe,.

\subsection{Research trends by research scholars}

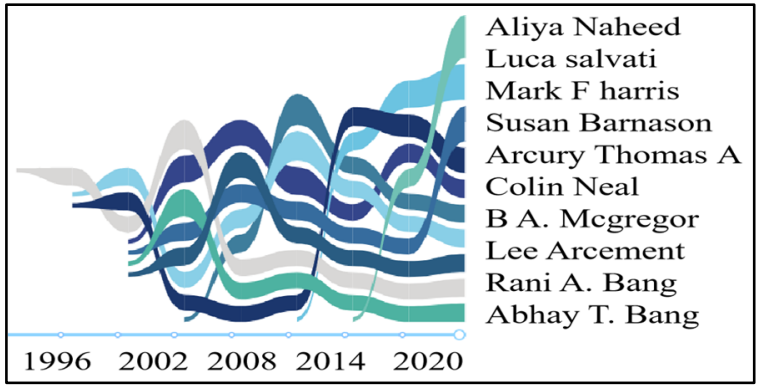

Fig. 4. Top 10 Research scholars

Figure 4 shows that the top 10 scholars in the field of Rural environmental governance research are: Aliya Naheed, Luca Salvati, Mark F Harris, Susan Barnason, Arcury Thomas, A Colin Neal, B A. Mcgregor, Lee Arcement, Rani A. Bang and Abhay T. bang.

\section{Distribution of related scholars and institutions}

\section{1 $\mathrm{H}$ index distribution of related scholars}

Table 1. H index distribution of related scholars.

\begin{tabular}{|c|c|}
\hline$H$ index range & Number of scholars \\
\hline 10 or less & 20683706 \\
\hline $10-20$ & 493055 \\
\hline $20-30$ & 116282 \\
\hline $30-40$ & 38791 \\
\hline $40-50$ & 15017 \\
\hline $50-60$ & 6710 \\
\hline Above 60 & 9044 \\
\hline
\end{tabular}

The $\mathrm{H}$ index is a method proposed by the American physicist Jorge E. Hirsch in 2005 to evaluate the academic achievements of scholars. A mixed quantitative method is used to evaluate the academic output quantity and academic output level of scholars at the same time. It can be found from Table 1 that the $\mathrm{H}$ index of most scholars is below 10 .

\subsection{Distribution of leading institutions in various countries}

As shown in Table 2, China's leading institutions in this field are the Chinese Academy of Sciences, Zhejiang University, Sichuan University, and Huazhong University of Science and Technology; the United States' leading institutions in this field are the University of Washington, the University of Minnesota, the University of Michigan, and the University of Florida; Japan's The leading institutions in the field are Kyoto University and Osaka University.

Table 2. Distribution of leading institutions.

\begin{tabular}{|c|c|c|}
\hline Institution & Country & $\begin{array}{c}\text { Number of } \\
\text { scholars }\end{array}$ \\
\hline $\begin{array}{c}\text { Chinese Academy of } \\
\text { Sciences }\end{array}$ & China & 51425 \\
\hline Zhejiang University & China & 29097 \\
\hline Sichuan University & China & 26100 \\
\hline $\begin{array}{c}\text { Huazhong University of } \\
\text { Science and Technology }\end{array}$ & China & 21799 \\
\hline Washington University & $\begin{array}{c}\text { United } \\
\text { States }\end{array}$ & 16870 \\
\hline University of Minnesota & $\begin{array}{c}\text { United } \\
\text { States }\end{array}$ & 16792 \\
\hline University of Michigan & $\begin{array}{c}\text { United } \\
\text { States }\end{array}$ & 15742 \\
\hline University of Florida & $\begin{array}{c}\text { United } \\
\text { States }\end{array}$ & 14196 \\
\hline Kyoto University & Japan & 14066 \\
\hline Osaka University & Japan & 11946 \\
\hline
\end{tabular}

\subsection{Institutional academic level distribution}

Table 3. Distribution of leading academic level.

\begin{tabular}{|c|c|c|c|}
\hline Institution & $\begin{array}{c}\text { Number of } \\
\text { papers }\end{array}$ & $\begin{array}{c}\text { Number of } \\
\text { scholars }\end{array}$ & $\begin{array}{c}\text { Average } \\
\text { citations }\end{array}$ \\
\hline $\begin{array}{c}\text { University of } \\
\text { California }\end{array}$ & 45 & 61 & 43.84 \\
\hline $\begin{array}{c}\text { Wageningen } \\
\text { University }\end{array}$ & 33 & 60 & 30.09 \\
\hline $\begin{array}{c}\text { University of } \\
\text { Zimbabwe }\end{array}$ & 30 & 43 & 17.17 \\
\hline $\begin{array}{c}\text { University of } \\
\text { Florida }\end{array}$ & 28 & 38 & 24.64 \\
\hline $\begin{array}{c}\text { Monash } \\
\text { University }\end{array}$ & 26 & 37 & 25.4 \\
\hline
\end{tabular}

Table 3 shows the number of articles published by major research institutions, the number of scholars, and the average number of citations. Among them, the number of papers and scholars of London School of Hygiene and Tropical Medicine is not the most, but the average citation number of its papers is the highest, reaching 78.04. 


\section{Cooperation network analysis}

\subsection{Global country cooperation analysis}

Table 4. Global country cooperation.

\begin{tabular}{|c|c|c|c|c|}
\hline $\begin{array}{c}\text { Country } \\
1\end{array}$ & $\begin{array}{c}\text { Country } \\
2\end{array}$ & $\begin{array}{c}\text { Number } \\
\text { of } \\
\text { papers }\end{array}$ & $\begin{array}{c}\text { Average } \\
\text { number } \\
\text { of } \\
\text { citations }\end{array}$ & $\begin{array}{c}\text { Number } \\
\text { of } \\
\text { citations }\end{array}$ \\
\hline China & $\begin{array}{c}\text { United } \\
\text { States }\end{array}$ & 199 & 41.74 & 8306 \\
\hline $\begin{array}{c}\text { United } \\
\text { Kingdom }\end{array}$ & $\begin{array}{c}\text { United } \\
\text { States }\end{array}$ & 48 & 39.57 & 1899 \\
\hline China & Australia & 38 & 29.76 & 1131 \\
\hline China & Canada & 34 & 41.88 & 1424 \\
\hline Canada & $\begin{array}{c}\text { United } \\
\text { States }\end{array}$ & 32 & 26.09 & 835 \\
\hline Australia & $\begin{array}{c}\text { United } \\
\text { States }\end{array}$ & 31 & 26.3 & 815 \\
\hline India & $\begin{array}{c}\text { United } \\
\text { States }\end{array}$ & 26 & 43.38 & 1128 \\
\hline China & Japan & 23 & 18.14 & 417 \\
\hline Australia & $\begin{array}{c}\text { United } \\
\text { Kingdom }\end{array}$ & 20 & 30.25 & 605 \\
\hline Brazil & $\begin{array}{c}\text { United } \\
\text { States }\end{array}$ & 19 & 36.32 & 690 \\
\hline
\end{tabular}

The situation of international cooperation can be reflected in Table 4. Country 1 is the nationality of the first author of the article, and Country 2 is the nationality of the second author and other authors. The research on Rural environmental governance in China and the United States belongs to the two countries with the most international cooperation. In second place is the cooperation between the United Kingdom and the United States. Other specific cooperation conditions can be obtained from Table 4 .

\subsection{Research institute cooperation statistics}

Table 5. Research institute cooperation statistics.

\begin{tabular}{|c|c|c|c|c|}
\hline Institute 1 & Institute 2 & $\begin{array}{c}\text { Number } \\
\text { of } \\
\text { papers }\end{array}$ & $\begin{array}{c}\text { Average } \\
\text { number } \\
\text { of } \\
\text { citations }\end{array}$ & $\begin{array}{c}\text { Number } \\
\text { of } \\
\text { citations }\end{array}$ \\
\hline $\begin{array}{c}\text { Western } \\
\text { Cape } \\
\text { University }\end{array}$ & $\begin{array}{c}\text { University } \\
\text { of } \\
\text { Zimbabwe }\end{array}$ & 4 & 20.25 & 81 \\
\hline $\begin{array}{c}\text { School of } \\
\text { Land } \\
\text { Resources } \\
\text { and } \\
\text { Environment }\end{array}$ & $\begin{array}{c}\text { Jiangxi } \\
\text { Unicultural }\end{array}$ & 3 & 18.67 & 56 \\
\hline $\begin{array}{c}\text { University of } \\
\text { New South } \\
\text { Wales }\end{array}$ & $\begin{array}{c}\text { University } \\
\text { of Sydney }\end{array}$ & 3 & 21 & 63 \\
\hline $\begin{array}{c}\text { Asian } \\
\text { Institute of } \\
\text { Technology }\end{array}$ & $\begin{array}{c}\text { University } \\
\text { of Stirling }\end{array}$ & 3 & 43 & 129 \\
\hline
\end{tabular}

Table 5 demonstrates Western Cape University and University of Zimbabwe collaborated with the largest number of papers, but from the perspective of citations, Asian Institute of Technology and University of Stirling have the highest number of citations.

\subsection{Statistics of International Scholar Flow}

Table 6. Statistics of International Scholar Flow.

\begin{tabular}{|c|c|c|c|}
\hline Country & inflow & outflow & net inflow \\
\hline United States & 596719 & 583923 & 12796 \\
\hline China & 178752 & 187354 & -8602 \\
\hline United Kingdom & 126269 & 119202 & 7067 \\
\hline Germany & 100356 & 93383 & 6973 \\
\hline Canada & 96516 & 93355 & 3161 \\
\hline France & 89009 & 88336 & 673 \\
\hline Japan & 67439 & 65049 & 2390 \\
\hline Italy & 49719 & 46616 & 3103 \\
\hline India & 48137 & 42923 & 5214 \\
\hline Australia & 37880 & 43813 & -5933 \\
\hline
\end{tabular}

\section{5 conclusions}

This article has studied the bibliometric issues of Rural environmental governance.

(1) The results of research trends show that: the United States first started relevant research; research hotspots include topics such as rural communities and public health; research institutions include the University of Zimbabwe, the University of Washington and so on; main research scholars include Aliya Naheed, Luca Salvati and so on..

(2) The results of distribution of research results show that: the $\mathrm{H}$ index of most scholars is less than 10; the main research institutions are concentrated in China, the United States and Japan; the research level is uneven.

(3) The results of the research cooperation network analysis show that there is more cooperation between China and the United States, Britain and the United States; Western Cape University and the University of Zimbabwe have more cooperation; the flow of scholars shows that the United States is a net inflow country.

\section{Acknowledgement}

The work presented in this paper was funded by 2019 Inner Mongolia Rural Pastoral Area Governance Modernization Research Base Project (No. NCZLJD201906).

\section{References}

1. Yu-Dan L, Ying L, Jian Z, Xiao-Yin W, Hui-Zheng Z, Xiu-Hua C. Study of acupuncture for low back pain in recent 20 years: a bibliometric analysis via CiteSpace. Journal of Pain Research: 951-964 (2017).

2. Meng W, Shen K, An Q. Visual Analysis of Real Estate Investment Trusts Research-A Bibliometric Analysis Based on CiteSpace III. American Journal of Industrial \& Business Management 12: 794-805 (2015).

3. Yu Y, Li Y, Zhang Z, Gu Z, Chen E. A bibliometric analysis using VOSviewer of publications on 
COVID-19. Annals of Translational Medicine 13: $816(2020)$.

4. Huang T, Wu H, Yang S, Su B, Tang K, Quan Z et al. Global Trends of Researches on Sacral Fracture Surgery: A Bibliometric Study Based on VOSviewer. SPINE: (2020).

5. Kataria A, Kumar S, Pandey N. Twenty-Five Years of the Gender, Work and Organization: A Bibliometric Analysis. Gender Work \& Organization:
(2020).

6. Kottala S, Kotzab H. The intellectual foundation of supply chain management performance models: a bibliometric analysis and synthesis. International Journal of Comparative Management 2: 67-91 (2019).

7. Wang J, Liu Z. A bibliometric analysis on rural studies in human geography and related disciplines. SCIENTOMETRICS 1: 39-59 (2014). 